\title{
Modality with Past Time Reference in English-into-Arabic Fiction Translation
}

\begin{tabular}{c}
\hline Mohammed Farghal \\
\hline Professor \\
Department of English \\
Kuwait University \\
m_farghal@hotmail.com
\end{tabular}

\begin{tabular}{c}
\hline Mashael Al-Hamly \\
\hline Associate Professor \\
Department of English \\
Kuwait University \\
mashael2@hotmail.com
\end{tabular}




\title{
Modality with Past Time Reference in English-into-Arabic Fiction Translation
}

\author{
Mohammed Farghal \& Mashael Al-Hamly
}

\section{Abstract}

Modality is a semantic medium that colors the way the language user views the world around him/ her in terms of certainty, necessity and obligation; hence, it places extra effort on the translator while attempting to capture modalistic shades of meaning. The task may become more challenging when the translator is dealing with a language pair where modality is grammar-oriented in one member (English, for example) and lexis-oriented in the other (Arabic, for example). The present paper aims to investigate the rendering of speaker participation in the speech event as embodied in modality when translating English fiction into Arabic. In particular, it will examine the corpus of two sets of data involving past modality (modal + have + past participle) extracted from two English novels which will be compared with their counterparts in the Arabic translations. Four main issues will be discussed. The first is to see whether the distinction between epistemic and deontic modality is maintained in translation. The second is to check whether the translators are sensitive to the import of modality in discourse as manifested in the speaker's attitudes toward what is happening. The third is to check whether English modalized propositions are sometimes erroneously rendered into modality-free Arabic propositions. Last, the study discusses the Arabic modality markers employed to capture past modality. Both a quantitative account (focusing on form and function) and a qualitative analysis (focusing on adequacy of translation procedures) are furnished.

Keywords: Grammar-Oriented Modality, Lexis-Oriented Modality, Past Tense, English Fiction into Arabic.

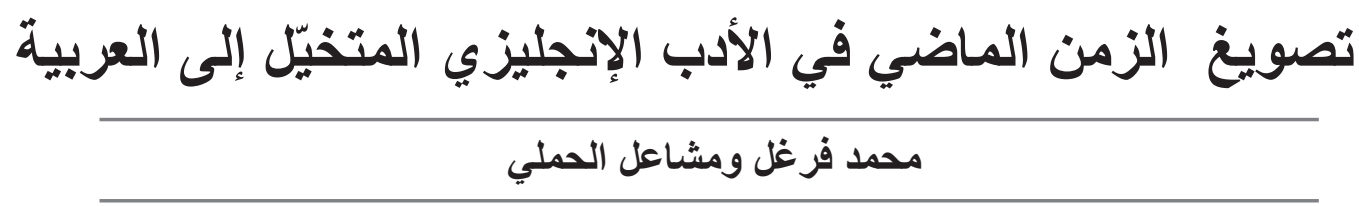

مستخلص

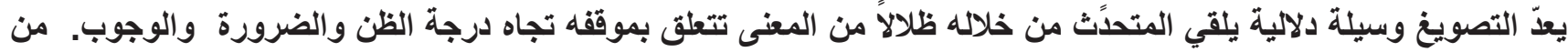

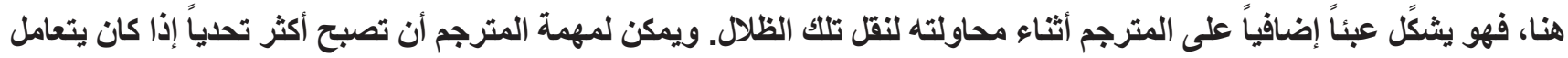

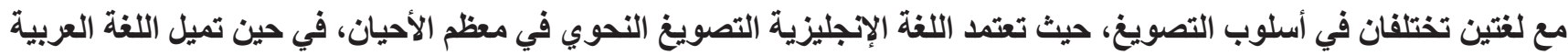

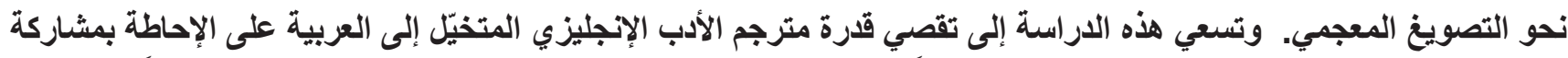

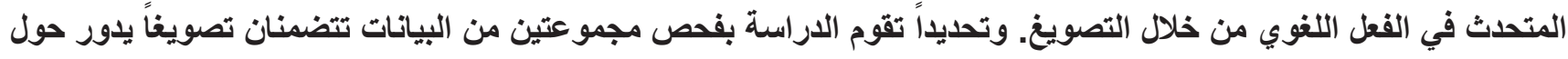

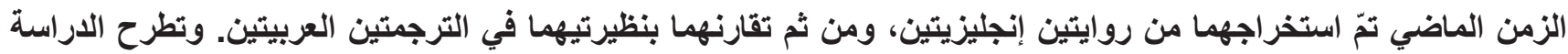

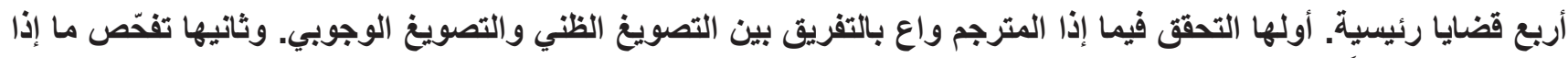

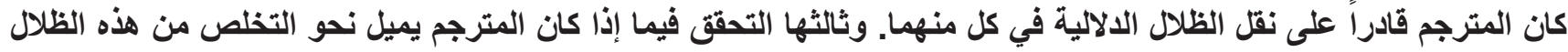

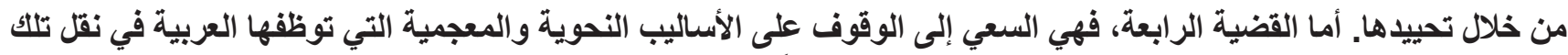
الظلال. وللتحقيق هذه الأهداف، تقدم الاراسة عرضاً كمّياً وتحليلاً نوعيّاً لتلك البيانات.

كلمات مفتاحية: التصويغ النحوي، التصويغ المعجمي، الزمن الماضي، الأدب الانجليزي المتخيل المترجم إلى العربية. 


\section{Introduction}

Most authors on the topic of modality (Halliday 1970; Lyons 1977; Perkins 1983; Coates 1983; and Palmer 1990; 2001, among others) divide English modal auxiliaries into two basic categories: epistemic and deontic. Epistemic modality involves the speaker's/writer's expressing his judgment of a state of affairs in terms of the likelihood of its occurrence apart from factual statements. For example, Mary is happily married expresses a factual statement from the speaker's perspective and is modality-free, i.e. the propositional content of the utterance is not interfered with by the utterance. By contrast, Mary may be happily married and Mary must be happily married involve the speaker's commitment to different degrees of certainty by employing the modals may and must epistemically. While the speaker expresses a weak degree of commitment in the former, $\mathrm{s} /$ he expresses a strong degree of commitment in the latter. For its part, deontic modality views any state of affairs in terms of necessity, which ranges between placing a strong obligation on the referent, e.g. Mary must see the manager and a weak one (permission), e.g. Mary may see the manager. Therefore, while epistemic modality views language as "information", deontic modality views it as "action" (Palmer 2001).

All accounts of English and Arabic modality emphasize the indeterminacy of the semantics of modal verbs where context plays a key role (compare the ability vs. the permission reading of Mary can speak French تستطيع ماري أن تتحدث الفرنسية), where English verb can and the Arabic modal verb both cause ambiguity which can be resolved only by referring to context. Sometimes, an English modal verb, e.g. must (which can be ambiguous between a deontic and an epistemic reading as in You must be very generous needs to be translated into two different modal verbs in Arabic (compare vs. يجب/ينبغي أن تكون كريماً لا بدّ أنكأ كريم, respectively). This indeterminacy parameter which plagues modality has not prevented some authors from suggesting some generalizations in the semantics of modal verbs/particles in English and Arabic.
Zayed (1984), for example, reduces the epistemic parameter in English and Arabic to may vs. must and rubamaa ربما vs. laa budda لا بدَّ بد, respectively, and the deontic parameter to may vs. must and yumkinu يمكن vs. yajibu يجب, respectively. De Haan (1997: 50) rightly improves on Zayed's typology by presenting each two items on separate continua, thus making it visible that the two types of modality exist in different degrees from weak to strong, as can be seen below:
a. Epistemic modality
Weak Strong
ربما لا بد

b. Deontic modality

Weak Strong<smiles>[AsH2]</smiles>
بجب.

Apart from assertive utterances (e.g. John traveled to London), which are modality-free, several semanticists (e.g. Palmer 2001; Huddleston and Pullum 2002; Nuyts 2001; Nuyts et al. 2005) talk about a third type of modality (dynamic modality), which is traditionally listed under deontic modality. Dynamic modality basically involves the use of the modal verbs can/could and will/would in utterances where they assert propositions about the subject of the sentence without any traces of the producer's engaging in modalizing the proposition, whether epistemically or deontically, e.g. $\mathrm{Na}$ dal can easily win the US Open this year and Nadal will participate in the US Open this year. Both examples assert propositions relating to the subject (Nadal) without the speaker committing himself to any kind of inference or placing any kind of obligation on anyone. Because of the non-modalistic nature of dynamic modality, Gisborne (2007) goes as far as removing this type from the domain of modality altogether, arguing for a grammaticalization process of the modals can and will in such cases.

In terms of translation, Baker (1992) divides modals into action modals (which express permitting, recommending or prohibiting) and belief modals (which express the speaker's beliefs about 
the likelihood of a certain situation). She asserts that translating modality between English and Arabic is problematic because English modals are mostly grammatical while their Arabic counterparts are mostly lexical. Most recent studies of Arabic modality (Zayed 1984; El-Hassan 1990; Farghal and Shunnaq 1999/2011; Abdel-Fattah 2005; Al-Qinai 2008; Al-Ashoor 2009; Wided 2010) reach the general conclusion that Arabic lacks a highly grammaticalized system of modals although it possesses the lexico-grammatical means to express modalistic shades of meaning in discourse. These authors mainly list English modal verbs along with their possible Arabic counterparts and exemplify their uses in decontextualized sentences (e.g. See Abdel-Fattah 2005 and Al-Qinai 2008) in terms of epistemic and deontic modality. Few studies (e.g. Badran 2001; Farghal and Beqri 2012), however, examine the translation of modal expressions between English and Arabic in authentic discourse. Badran shows that Arabic modal expressions in political discourse may be manipulated when translated into Arabic, while Farghal and Beqri indicate that 39/166 cases of English modals are rendered into zero-equivalents in the translation of Macbeth into Arabic.

The present study deals with an aspect of modality (modality with past tense reference (modal + have + past participle) involving hypothetical and/ or inferencing nuances) which has not been addressed in translating English modals into Arabic. As has been mentioned above, previous studies mainly address the translation of decontextualized sentences featuring English modals with present/ future tense. In terms of translation, one should note that what is an unmarked reading of an English modal in present/future tense reference embraces a different type of modality in past tense reference. Compare, for example, the sentences John must travel to London and John must have traveled to London. Whereas the former has an unmarked deontic reading (placing a strong obligation on the referent), the latter exclusively has an epistemic reading (the speaker committing himself/herself to a strong inference). Besides, the dynamic modality of can and will becomes combined (a combination of deontic and epistemic modality), e.g. John could have passed the exam and hypothetical, e.g. John would have the exam respectively in past modality. The discrepancy between modality in present/future and past time reference would, therefore, involve some subtleties in English-into-Arabic translation which need to be investigated.

\section{Objectives of Study}

This study aims to answer the following questions:

1- Do the translators capture the difference between epistemic vs. deontic vs. combined past modality when translating English fiction into Arabic?

2- Do the translators manage to relay the language user's shades of meaning which are embodied in the use of English modals in Arabic translation?

3- Does the problematic nature of English modals sometimes force the translators to render modalistic states of affairs as modality-free ones?

4- What modality markers does Arabic employ to express past modality?

\section{Methodology}

The study employs a data-based methodology. A corpus of two sets of data featuring the use of past modality will be extracted from two English novels: Oracle Night (P. Auster 2003, translated into Arabic by M. Abdulsalam 2008) and The Great Gatsby (S. Fitzgerald 1925, translated into Arabic by N. Al-Manea 1962). The data consists of all instances of past modality in the two novels (53 from Oracle Night and 49 from The Great Gatsby).

\section{Discussion of Data}

\section{English Corpus}

The corpus collected from Oracle Night and The 
Great Gatsby consists of 102 instances of using past modality (modal + have + past participle) distributed as shown in Table 1 and 2 below:

Table 2: Epistemic vs. Deontic vs. Combined Modality in English Corpus

\begin{tabular}{|c|c|c|c|}
\hline Type & ON & GG & Total \\
\hline Epistemic & $45(44.1 \%)$ & $38(37.3 \%)$ & $84(82.4 \%)$ \\
\hline Deontic & $6(5.9 \%)$ & $5(4.9 \%)$ & $11(10.8 \%)$ \\
\hline Combined & $1(1 \%)$ & $6(5.9 \%)$ & $7(6.9 \%)$ \\
\hline
\end{tabular}

As can be seen, Table 1 shows the frequency of employing English modal verbs in past modality in the two novels separately and combined. As for Table 2, it divides the occurrences of past modality in the two novels separately and combined into epistemic, deontic and combined. The epistemic category involves the use of must, would, may, might, can't, while the deontic group features should and ought to. As for the combined category, it involves the use of could and couldn't, where 'ability' shades into 'probability', thus giving a mixed perspective by the producer. Following are three examples from the corpus, alongside their proper Arabic renderings representing the three categories, respectively:

1. Bravo. It must have been hard. (ON)

$$
\text { بر افو. لا بدّ أن الأمر كان صعبا. }
$$

2. I ought to have left it in the shade. (GG)

$$
\text { لقد كان ينبغي أن أضعها في الظل. }
$$

3. I could have sworn I heard the owl-eyed man break into ghostly laughter. (GG)

$$
\text { كان بوسعي أن أقسم أن الرجل ذا العيون البوم... }
$$

In the above examples, whereas (1) commits the producer to a very strong inference, (2) places a strong, unrealized obligation on the producer. For its turn, (3) views the unrealized past act (i.e. the producer's swearing) as both manageable and probable, thus combining deontic and epistemic modality.

\section{Translation Corpus}

\subsection{Epistemic vs. Deontic vs. Combined}

In response to the first research question regarding the translator's awareness of the distinction between epistemic, deontic and combined modality, two main observations can be made when examining the corpus. The first indicates that when English past modality is rendered in Arabic translation, the translators of the two novels under study are generally aware of the difference between epistemic and deontic modality in terms of expressing commitment to an inference vs. placing an obligation on some party. The second observation shows that both translators render several cases of epistemic modality into dynamic modality, as well as rendering some cases of deontic modality into dynamic modality (which applies to The Great Gatsby only). Table 3 below shows the frequency of these cases in the two novels separately and combined:

Table 1: Type of modal auxiliary in English corpus

\begin{tabular}{|l|c|c|c|}
\hline Modal & Oracle Night (ON) & The Great Gatsby (GG) & Total \\
\hline ought to/ should & $7(6.9 \%)$ & $5(5 \%)$ & $12(11.8 \%)$ \\
\hline Would & $20(19.6 \%)$ & $8(7.8 \%)$ & $28(27.5 \%)$ \\
\hline might/ may & $17(16.7 \%)$ & $11(10.8 \%)$ & $28(27.5 \%)$ \\
\hline Must & $7(6.9 \%)$ & $19(18.6 \%)$ & $26(25.5 \%)$ \\
\hline can't & $1(1 \%)$ & $0(0 \%)$ & $1(1 \%)$ \\
\hline could/couldn't & $1(1 \%)$ & $6(5.9 \%)$ & $7(6.9 \%)$ \\
\hline Total & $53(52 \%)$ & $49(48 \%)$ & 102 \\
\hline
\end{tabular}


Table 3: Distribution of Arabic renderings in terms of Epistemic vs. Deontic vs. Combined

\begin{tabular}{|l|c|c|c|c|}
\multicolumn{2}{|c|}{} & $\begin{array}{c}\text { Correct } \\
\text { Type }\end{array}$ & $\begin{array}{c}\text { Dynamic } \\
\text { Modality }\end{array}$ & \multicolumn{1}{|c|}{ Total } \\
\hline ON & Epistemic & $31(30.4 \%)$ & $5(5 \%)$ & $36(35.3 \%)$ \\
\hline \multirow{2}{*}{ Deontic } & $7(6.9 \%)$ & 0 & $7(6.9 \%)$ \\
\hline Combined & 0 & 0 & 0 \\
\hline Epistemic & $34(33.3 \%)$ & 0 & $34(33.3 \%)$ \\
\hline Deontic & $3(2.9 \%)$ & 0 & $3(2.9 \%)$ \\
\hline Combined & $4(3.9 \%)$ & $2(2 \%)$ & $6(5.9 \%)$ \\
\hline & Total & $79(77.5 \%)$ & $7(6.9 \%)$ & $86(84.3 \%)$ \\
\hline
\end{tabular}

Excluding Modality-free Renderings (17/102, Section 4.2 .3 below), Table 3 shows that the translators have generally maintained the distinction between epistemic and deontic modality, viz. out of 80 renderings (having excluded the 6 instances of the combined category) 75 have maintained the distinction. Following are some illustrative examples:

4. You must have gone to church once. Didn't you get married in a church? (GG, p. 168)

(commitment to strong inference)

$$
\text { لا بدّ انك ذهبت مرة إلى الكنيسة، ألم تتزوج في كنيسة ما؟ }
$$

5. Robson may well have kept a diary. (ON, p. 20) (commitment to a weak inference)

$$
\text { ريما كان روبسون يمتلك دفتر يو ميّات. }
$$

6. Adrian should have gone snooping, or saved up his pocket money. (ON, p. 17)

(placing a strong obligation)

$$
\text { كان على أدريان أن يتقصى الأخبار، أو أن يوفر مصروفه. }
$$

7. I ought to have left it in the shade. (GG, p. 128) (placing a strong obligation)

$$
\text { لقد كان ينبغي أن أضعها في الظل. }
$$

The remaining 5 instances (they all come from ON) involve English epistemic cases that have been rendered into Arabic dynamic modality where there is no trace of the producer's perspectivizing or inter- fering with the proposition, i.e. the proposition is simply asserted by the employment of the Arabic future modal verb سوف 'will' or the synonymous future prefix will' to express an assertion in the future. Below are two illustrative examples:

8. And don't forget that in the present case there would have been an inquest. (ON 19)

(a hypothetical past act)

$$
\text { ولا تتس في حالتنا هذه سيكون هنالك استجو اب. (30) }
$$

(an asserted future act)

\section{I imagine the Foreign Office would have} contacted the embassy in Washington ... (ON 51) (a hypothetical past act)

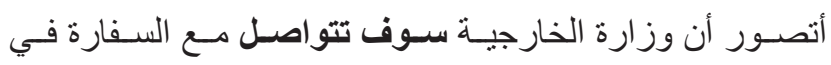
واشـنطن. (62) أصنورة

(an asserted future act)

As can be observed, what is epistemically modalized in English in (8) and (9) is asserted by dynamic modality in the Arabic renderings respectively. Therefore, the English back translations of the Arabic renderings would be (10) and (11) respectively:

10. And don't forget that in our present case there will be an inquest.

11. I imagine that the Foreign Office will contact the embassy in Washington ...

To epistemically modalize the two propositions in Arabic, one needs to employ the past form of the Arabic copula, i.e. كان 'was' immediately before the modal auxiliary, as can be seen in (12) and (13) below respectively:

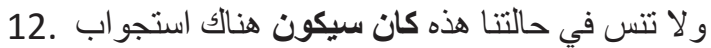

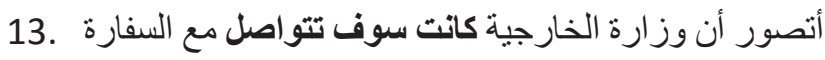

$$
\begin{aligned}
& \text { في واشنطن }
\end{aligned}
$$

To avoid the use of two copulas in (11) and to improve the naturalness of (13), one would offer (14) and (15) below:

$$
\begin{aligned}
& \text { 14. 14 النس في حالتتا هذه كان سيحدث هنالك استجواب }
\end{aligned}
$$

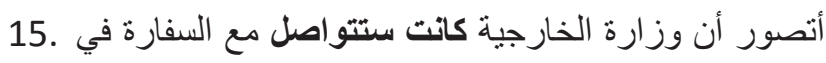

$$
\begin{aligned}
& \text { و واشنطن }
\end{aligned}
$$


Moving to combined modality, the 8 instances (see Table 2 above) are rendered into 4 combined, 2 dynamic, and two modality-free in Arabic. Following are 3 illustrative examples representing these types of rendering respectively:

16. I could have gone deeper if I'd known. (GG 129) ولقد كنت أستطيع أن أتعمق في الأمر لو علمت. (161)

17. I could have sworn he was trembling ... (GG 25) فإني أستطيع أن أقسم أنه كان يرتجف ... (30)

18. While I could hardly have expected a farewell letter ... (ON 56)

$$
\text { في حين لم أتوقع أن تصلني رسالة وداع ... (69) }
$$

The English sentence as well as its Arabic rendering in (16) features combined modality where epistemic and deontic modalities are shaded into each other, i.e. the speaker expresses a hypothetical past act involving both ability and probability. In (17), by contrast, combined modality is shifted into dynamic modality where 'the act of swearing' is asserted rather than hypothesized/imagined. For its turn, the combined modality in (18) is removed altogether by rendering the English utterance into a modality-free Arabic utterance (see Section 4.2.3 on modality-free renderings). To see the discrepancy more clearly, following are the back translations of the Arabic renderings in (17) and (18) respectively:

19. I can swear he was trembling ...

20. While I didn't expect a farewell letter ...

While (19) asserts the proposition using dynamic modality, (20) does away with modality by just negating the proposition. To properly modalize the Arabic renderings in (17) and (18), one may offer (21) and (22), respectively:

كان بوسعي أن أقسم أنه كان برتجف . 21

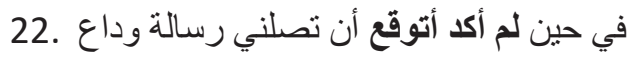

One should note that combing epistemic and deontic in could + have+ past participle in English can be variously captured by employing the modalizing expressions كان بوسع، كان باستطاعة or كان بمقدور.

\subsection{Erroneous Renderings within Epistemic and Deontic Modality}

In response to the second research question regarding the translators' ability to capture the different nuances within deontic and epistemic modality, the translation corpus shows the following figures for erroneous renderings:

Table 4: Erroneous Renderings within Deontic and Epistemic Modality

\begin{tabular}{|c|c|c|c|}
\hline & ON & GG & Total \\
\hline Deontic & $0 / 7(0 \%)$ & $0 / 3(0 \%)$ & $0 / 10$ \\
\hline \multirow{2}{*}{ Epistemic } & $12 / 45$ & $5 / 38$ & $17 / 83$ \\
& $(26.7 \%)$ & $(13.2 \%)$ & $(20.5 \%)$ \\
\hline
\end{tabular}

Table 4 shows that there are no erroneous renderings when rendering English deontic modality into Arabic deontic modality. Apparently, when rendering an unrealized English past obligation (should/ ought to + have + past participle) into its Arabic counterpart (e.g. كان على/ كان ينبغي, among others), the translators have done this correctly, as can be illustrated in the two examples below:

23. Adrian should have gone snooping, or saved up his pocket money. (ON, p. 17)

كان على أدريان أن يتقصى الأخبار ، أو أن يوفر مصروفه. (p. 85)

24. I ought to have dropped you in West Egg, Nick. (GG, p. 152)

كان ينبغي أن أنزلك في البيضة الغربية يا نيك ... (p. 189)

By contrast, Table 4 instantiates 17 (20.5\%) instances of erroneous nuances in the two novels when rendering English epistemic modality into its Arabic counterpart. Following are some illustrative examples:

25. In another mood I might have taken this as a strike against the three of us. (ON, p. 36) لو كنا في مز اج آخر لكنت فسرت ذلك على أنه ضربة ضدنا جميعا. (p. 48)

26. I searched for any moment, incident or remark which might have seemed worthy. (ON, p. 70) بحثت عن أي لحظة أو حدث أو إثارة قد تستحق التقدير و المكافأة. (p. 81) 
27. If I had thought of it all, I would have thought of it as a thing that merely happened, ... (GG, p.79) ولكني إن فكرت بذلك يوما ما فقد حسبث أن الأمر قد حدث على نحو ما، ... (p. 99)

28. I realize now that under different circumstances that conversation might have been one of the curses of my life. (GG, p.89) إنني أدرك الآن أن هذه المحادثة لو كانت الظروف غير ما كانت،

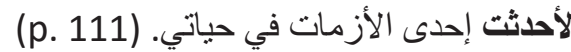

To start with (25), the translator has rendered an English past hypothetical act which might have occurred into an Arabic past hypothetical act which was bound to occur, thus changing the speaker's commitment to the degree of certainty (i.e. from strong degree to a weak one). To capture a similar degree of certainty, one may suggest (29) below:

29. لو كنا في مز اج آخر لريما فسرت ذلك على أنه ضربة ضدابل جميعا

The modality problem in the Arabic rendering of (26) has to do with confusing a past hypothetical state of affairs which might have occurred with a real state of affairs that might occur. This serious problem stems from the translator's use of the modal particle قد wich is employed in Arabic to express the speaker's weak commitment to a state of affairs relating to the present or future, but not the past, where لعل كان or ربما كان are used. In this way, the Arabic rendering back-translates into (30) below:

30. I searched for any moment, incident or remark which might seem worthy.

To capture the modality in (26), one can offer (31) below:

$$
\text { بحثت عن أبي لحظة أو حدث أو إثارة ربما كاتت تستحق.31 }
$$

For its turn, the Arabic rendering of (27) can hardly make any sense because the logic is fallacious, i.e. there cannot be congruence between a conditional possible future state of affair and its past realized one. In this way, the Arabic translation would back-translate into something like 'But if I think of that one day then I had thought that the thing had happened somehow, ...', which does not make sense for the same reason. Apparently, the translator is totally confused. First, he mistakenly employs the Arabic conditional marker إن (which marks real conditions) with لو (which indicates hypothetical conditions). Second, as a result of the first mishap, he failed to modalize the hypothetical act in the result clause. This two-fold problem has led to fallacious logic in his rendering. To capture modality in (27), one may offer (32) below:

ولكنني لو كنت فكرت بذللك يوما، لكنت حسبت الأمر حدث . على نحو ما تلكا

Last, the Arabic rendering of (28), just like that of (25), has changed the degree of hypothetical certainty from weak to strong. To remedy this mishap, one can offer (33) below:

$$
\begin{aligned}
& \text { 34. إنني أدرك الآن أن هذه المحادثة لو كانت الظروف غير الأن التان } \\
& \text { كانت، لربما أحثث إحدى الأزمات في حياتي }
\end{aligned}
$$

Before closing this section, it is interesting to note that there is one instance where epistemic modality is erroneously rendered as combined modality, as can be observed in (35) below:

35. I would have accepted without question. (GG, 54) لقد كان بوسعي أن أقبل دون سؤال ...(p8)

While the speaker in (35) expresses his commitment to the certainty of a past hypothetical act, the Arabic rendering combines deontic and epistemic modality by expressing the speaker's past hypothetical ability to perform the act in question as well as its past hypothetical likelihood. In this way, the Arabic rendering back-translates into (36) below:

36. I could have accepted without question ...

To capture the modality in (35), one may offer (37) in Arabic:

$$
\text { 37. قلق كنت سأقبل دون سؤ ال }
$$

\subsection{Modality-free Renderings}

In response to the third research question, Arabic modality-free renderings refer to those ones which do not exhibit any type of modality in con- 
trast with the English utterances which modalize their relevant states of affairs. Thus, modality in English is dispensed with by reducing it to zero-level in Arabic renderings. Table 5 below accounts for modality-free renderings in the corpus:

Table 5: Distribution of Modality-free Renderings in the Data

\begin{tabular}{|c|c|c|c|}
\hline & ON & GG & Total \\
\hline \multirow{2}{*}{ Deontic } & $1 / 8$ & $3 / 11$ & $4 / 19$ \\
& $(12.5 \%)$ & $(27.3 \%)$ & $(21.1 \%)$ \\
\hline \multirow{2}{*}{ Epistemic } & $10 / 45$ & $3 / 38$ & $13 / 83$ \\
& $(22.2 \%)$ & $(7.9 \%)$ & $(15.6 \%)$ \\
\hline
\end{tabular}

Following are some illustrative examples of modality-free renderings:

38. Not that she would have put it like that.

$$
\text { لا أقول إنها كاتت تعبر عن الأمر بتلك الطريقة. }
$$

39. So Mr. Ford's guided tour as he drove us along must have been fanciful - some private joke. إذن جولة السيد فورد السياحية أثناء قيادة السيارة كانت وهية،

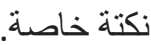

40. It was a matter of chance that I should have rented a house in one of the strangest communities in North America.

وقد كان من قبيل الصدفة أنني استأجرت منزلاً يقع في مكان من النا أغرب الأمكنة في أمريكيا الثمالية.

41. Anybody would have said that they were conspiring together. (GG, p. 55)

$$
\text { و الناظر إليهما يقول إنهما يتآمر ان معا. }
$$

All the modalized English utterances in (38-41) have been translated into modality-free Arabic utterances. While the English utterance in (38) refers to a hypothetical past state of affairs, the Arabic rendering asserts a real past state of affairs, thus reducing modality to zero-level. The Arabic rendering back-translates into 'I'm not saying that she was expressing it like that'. The question is whether the referent expressed anything in the first plate; the speaker in the English utterance just contemplates what the referent would have done. To capture this modalized proposition, one can offer لا أقول إنها كاتت ستعبر عن الأمر بتلك الطريقة.

In (39), the speaker's commitment to a past strong inference is rendered in Arabic as a an asserted past proposition, i.e. a modality-free proposition. Thus, the speaker's conclusion that 'Mr. Ford's tour must have been fanciful' is changed to the speaker's assertion that 'Mr. Ford's tour was fanciful'. To capture this nuance of modality in Arabic, one can offer إذن لا بدّ أن جولة السيد فورد السياحية ... كانت و همية

For its turn, (40) views a realized state of affairs as a past obligation on the speaker, i.e. the speaker happened to have the obligation to rent a house. This nuance of deontic modality is reduced to zero-level modality in the Arabic rendering, which back-translates into 'It was a matter of chance that I rented a house .... To add deontic modality to the وقد كان من قبيل الصدفة Arabic rendering, one can offer أنه كان عليّ أن أستأجر منز لاً ....

The last example (41) refers to a hypothetical situation where the referent would have said something, whereas its Arabic translation refers to a real situation where the referent is saying something. Thus, the Arabic rendering back-translates into 'And the onlooker says that they are conspiring together'. To capture the modality as embodied in the hypothetical situation, the Arabic rendering may look like و الناظر إليهما كان سيقول أنهما كانا يتآمر ان معا.

\subsection{Arabic Markers of Past Modality}

The data offers a variety of Arabic markers of past modality. This section will mention these markers and exemplify them by utterances from the corpus. The markers will include only those rendered properly from English into Arabic.

\subsubsection{Deontic Modality}

Deontic modality does not seem to pose a serious problem to both translators. The deontic corpus features 10 proper renderings out of 11 instances 
(about 91\% accuracy) distributed as shown in Table 6 below:

Table 6: Distribution of Arabic Proper Deontic markers

\begin{tabular}{|c|c|c|c|}
\hline Marker & ON & GG & Total \\
\hline كان من الدفترض & 1 & 0 & $1(1 \%)$ \\
\hline كان & 3 & 0 & $3(3 \%)$ \\
\hline كان يجدر حرياب & 1 & 0 & $1(1 \%)$ \\
\hline كان ينبغي & 2 & 0 & $2(2 \%)$ \\
\hline
\end{tabular}

As can be seen in Table 6, the range of Arabic deontic markers covers the most familiar tools, viz. the modalizing particle على, the modalizing verb ينبغي and lexically modalizing expressions such as and حريا anere is one interesting observation in the above Table. That is, the choice between the most frequent makers (كان على and كان ينبغي) is clearly governed by the translator's preference, viz. while كان على is employed in ON, it is not in GG, and the converse applies to كان ينبغي.

Following are illustrative examples of all the markers in Table 6:

كان من المفترض - كان

This ought to have given him a whole store tank of existential rage.

وكان ذلك من المفترض أن يمنحهمخزوناضخمامن الغضب الوجودي.

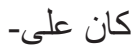

Perhaps all four of us should have gone off on a Quest to Discover the Truth.

ربما كان على أربعتنا أن نقوم برحلة بحث عن الحقيقة.

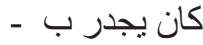

I should never have agreed to meet ... you

$$
\text { كان يجدر بي ألا أو افق على لقائك .... }
$$

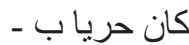

I shouldn't have been surprised.

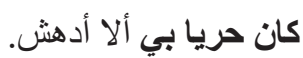

- I ought to have left it in the shade.

$$
\text { لقد كان ينبغي أن أضعها في الظل. }
$$

\subsubsection{Epistemic Modality}

Epistemic modality seems to involve a problematic area to both translators in contrast with deontic modality, viz. the corpus attests 49 proper renderings out of 83 instances (only 59\% accuracy). The distribution of the most frequent proper epistemic markers is displayed in Table 7:

\begin{tabular}{|c|c|c|c|}
\hline Marker & ON & GG & Total \\
\hline لا بدّ & $\begin{array}{c}3 \\
(6.1 \%)\end{array}$ & $\begin{array}{c}17 \\
(347 \%)\end{array}$ & $\begin{array}{c}20 \\
(40.8 \%)\end{array}$ \\
\hline ل & $\begin{array}{c}44 \\
(89.8 \%)\end{array}$ & $\begin{array}{c}2 \\
(4.1 \%)\end{array}$ & $\begin{array}{c}6 \\
(12 \%)\end{array}$ \\
\hline كان س & $\begin{array}{c}5 \\
(10.2 \%)\end{array}$ & 0 & $\begin{array}{c}5 \\
(10.2 \%)\end{array}$ \\
\hline ربما كان & $\begin{array}{l}2 \\
(4.1 \%)\end{array}$ & $\begin{array}{c}2 \\
(4.1 \%)\end{array}$ & $\begin{array}{c}4 \\
(8.2 \%)\end{array}$ \\
\hline لعل كان & $\begin{array}{c}1 \\
(2 \%)\end{array}$ & $\begin{array}{c}2 \\
(4.1 \%)\end{array}$ & $\begin{array}{c}3 \\
(6.1 \%)\end{array}$ \\
\hline يحتمل & 0 & $\begin{array}{r}3 \\
(6.1 \%)\end{array}$ & $3(6.1 \%)$ \\
\hline كان يمكن & 0 & $\begin{array}{c}2 \\
(4.1 \%)\end{array}$ & $\begin{array}{c}2 \\
(4.1 \%)\end{array}$ \\
\hline mixed bag & $\begin{array}{c}5 \\
(10.2 \%)\end{array}$ & $\begin{array}{c}1 \\
(2 \%)\end{array}$ & $\begin{array}{c}6 \\
(12.2 \%)\end{array}$ \\
\hline Total & $\begin{array}{c}20 \\
(40.8 \%)\end{array}$ & $\begin{array}{c}29 \\
(59.2 \%)\end{array}$ & $\begin{array}{c}49 \\
(100 \%)\end{array}$ \\
\hline
\end{tabular}

Table 7: Distribution of Proper Epistemic Markers

As can be observed in Table 7, the inferential is the most frequent marker of epistemic modality in Arabic, viz. it accounts for about $41 \%$ of the epistemic markers employed correctly. This modalizing marker indicates the producer's robust commitment to a conjecture based on what $s /$ he judges as strong evidence, as can be illustrated by the examples below:

42. Bravo. It must have been hard. (ON, p. 40)

$$
\text { بر افو. لا بـ أن الأمر كان صعبا (p2 (p2) }
$$

43. You must have gone there about the time $\mathrm{Bi}$ loxi went to New Haven. (GG, p. 137) 


$$
\text { لا بـ أنك ذهبت هناك في الوقت الذي ذهب فيه بيلوكسي إلى نيو }
$$$$
\text { هافن. (p. 170) }
$$

44. She must have broken her rule against drinking that night ... (GG, p. 166)

ولا بد انها قد كسرت في تللك الليلة نظامها القاضي بعدم الثرب ...

The next markers in frequency are the synonymous كان س and w w which account for 6 and 5 instances (10\% and $12 \%)$ respectively, are used to express the speaker's absolute commitment to a hypothetical situation in the past. Following are some illustrative examples:

45. If that's where it had been, Mrs. Ford would have seen it ... (ON, p. 110)

لو كان تركها هناك، لرأتها السيدة فورد (p. 123)

46. I wouldn't have been surprised to see sinister faces. (GG, p. 153)

$$
\text { ما كنت لأعجب لو رأيت وجو ها نحسة (190 ) }
$$

47. Adrian would have wanted first. (ON, p. 53)

$$
\text { أدريان كان سيسعى إلى الجائزة الأولى ( p5 (p5) }
$$

48. Anyone would have thought we were tourists. (ON, p. 33)

$$
\text { كان أي شخص سيعتقد أننا سو اح (p. p5) }
$$

As can be seen, the producers of (45-48) absolutely commit themselves to what would have happened. They express their hypothetical certainty toward hypothetical state of affairs in the past by the employment of would + have + past participle in English and the markers J and كان س in Arabic.

Apart from the mixed bag, the rest of the markers (ربما كان, لعل كان, يحتمل and كان يمكن) express the speaker's weak commitment toward a past hypothetical state of affairs. They account for 12 instances (about 24.5\%). Following are some illustrative examples:

49. Or he might have suffered guilt and remorse. (ON, p. 58)

$$
\text { أو ربما كان سيعاني من الذنب و الندم (p }
$$

50. ... people in it who might once have seen the pale of magic of her face along the casual street. (GG, p. 163)

وفيها أناس يحتمل أنهم رأوا السحر الثاحب في وجهها خلال الثوارع (GG

51. To a certain temperament the situation might have seemed intriguing ... (GG, p. 19)

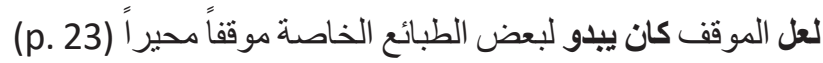

52. It might have lasted indefinitely except for the fact that Ella Kaye came on board on night. (GG, p. 107)

$$
\text { وقد كان يمكن لهذه الحالة أن تستمر إلى أمد غير محدود لو لا أن }
$$$$
\text { (p. 133)... }
$$

As can be seen, the speakers in (49) and (52) commit themselves to a mere hypothetical possibility in the past, i.e. a weak commitment.

Finally, the mixed bag features less familiar markers (one instance each) that may capture epistemic modality, as can be illustrated in the examples below:

53. As I started to do the same, she said, "Stay" I might have been a dog. (ON, p. 139)

حين همثت أن أفعل منلها قالت: ((ابق)) كأني كنت كلبا (p. 154)

54. I may have put it as badly as this when I tried to explain the feeling. (ON, p. 27)

$$
\begin{aligned}
& \text { ولعلني عبّرت عن ذلك بهذه الطريقة السيئة حين حاولت أن أفسر } \\
& \text { ما أنثعر به (p. 38) }
\end{aligned}
$$

55. ..., and there was a story that he'd agreed to pay five years' taxes on all the cottages if the owners would have their roofs thatched with straw. (GG, p. 94)

.... لو أن أصحابهاو افقو ا على أن يسققو اسطوحها بالقش. (p.118)

In the Arabic rendering of (55), the translator كأني لربما كنت or لعلني كنت 'I might have been' to capture the speaker's weak commitment, which may sound workable in this context. In (54), we find لعل plus an Arabic lexical 
verb (عبّرت) rather than the copula (كان) as in (51) above. It should be noted that لعل is used with the copula when the reference is to a state (51 above), whereas it comes with a lexical verb when the reference is to an act ( 54 above). Finally, the hypothetical causative would have [their roofs] thatched is properly rendered by لو أن (أصحابها) و افقوا thus capturing the hypothetical conditionality.

\section{Conclusions}

Several conclusions can be drawn from this study. Firstly, while the distinction between deontic and epistemic modality is generally captured by the translators of the two novels (75/80 instances observe the distinction), epistemic modality (in contrast with deontic modality) proves to be more challenging when it comes to capturing the nuances within each category, viz. there are no erroneous renderings within the deontic category, whereas the corpus instantiates 17/83 (20.5\%) erroneous renderings within the epistemic category. This finding points to the importance of alerting student translators as well as translation practitioners to nuances involved within epistemic modality, especially the difference between the speaker's committing himself to a weak vs. a strong past inference.

Secondly, the Arabic corpus shows 5/102 (5\%) instances of dynamic modality which all correspond to English epistemic counterparts. This indicates that the translators sometimes confuse epistemic modality with dynamic modality where the speaker asserts a proposition via سوف/س, which corresponds to 'will' in English. We have seen that such a modal does not perspectivize the speaker's orientation toward the proposition he expresses but rather merely asserts it, i.e. reducing it to zero-level modality. Similarly, combined modality bas been confused with dynamic modality, viz. 2 out of the 6 cases of combined are rendered into dynamic modality. Hence, it is important for translators to be sensitive to the difference between epistemic and combined modality on the one hand and dynamic modality on the other in English/Arabic translation.
Thirdly, modality-free Arabic renderings have their share in the corpus (17/102 - 16.66\%). Together with other inaccurate renderings (17 erroneous renderings within the epistemic category and 7 dynamic modality renderings) account for 41 instances (a fully $40.2 \%$ of the entire corpus). This significant finding proves beyond doubt that even professional translators are in serious need of remedial work in the area of translating English past modality into Arabic.

Finally, the present study provides a frequency data-based listing of the Arabic modal markers that may be employed in all types of past modality, i.e. deontic, epistemic and combined. Such a listing can be taken as a preliminary step toward standardizing modal markers in a scantily researched messy area in Arabic grammar.

\section{References}

Abdel-Fattah, M. (2005). On the translation of modals from English into Arabic and vice versa: The case of deontic modality, Babel, 51 (1), 31-48.

Abdulsalam, M. (2008). laylalat al-tanabbu' (trans. of Oracle Night). Ibdaat alamiyah 370. (Kuwait)

Al-Ashoor, A. (2009). The translation of modality from English into Arabic. Tikrit University Journal for Humanities, 16 (5), 50-70.

Al-Manea, N. (1962). ghasbi al-'adhiim 'The Great Gatsby' (trans). Baghdad: Franklin.

Al-Qinai, J. (2008). On translating modals. Translation and Interpreting Studies, 3 (1\&2), 30-67.

Auster, P. (2003). Oracle Night. New York: Henry Holt.

Badran, Dany. (2001). Modality and ideology in translated political texts. Nottingham Linguistic Circular, 16, 47-61. 
Baker, M. (1992). In other words: A coursebook on translation. London: Routledge.

Coates, J. (1983). The semantics of the modal auxiliaries, London: Croom Helm.

De Haan, F. (1997). The interaction of modality and negation: A typological study, New York: Garland Publishing.

El-Hassan, S. (1990). Expressing modality in English and standard Arabic. Journal of King Saudi University, 2 (2), 149-166.

Farghal, M. and Beqri, A. (2012). An analysis of into-Arabic translations of English modals in Shakespeare's Macbeth: The perils of translating English equivalents by zero equivalents. (2012). Journal of Interpreting and Translation Studies, 16 (3), 289-308.

Farghal, M. and Shunnaq, A. (1999/2011). Translation with reference to English and Arabic: $A$ practical guide. Irbed: Dar Al-Hilal for Translation.

Fitzgerald, S. (1925). The Great Gatsby. New York: Charles Scriber's Sons.

Gisborne, N. (2007). SKASE Journal of Theoretical Linguistics 7 (2) [online]. available at http://www. skase.sk/Volumes/JTL09/pdf_doc/4.pdf

Halliday, M.A.K. (1970). Functional diversity in language as seen from a consideration of modality and mood in English. Foundation of Language, 6, 322-361.

Huddeleston, R. and Pullum, G. (2002). The Cambridge grammar of English. Cambridge: Cambridge University Press.

Lyons, J. (1977). Semantics. Cambridge: Cambridge University Press.
Nuyts, J. (2001). Epistemic modality, language and conceptualization. Amsterdam: John Benjamins.

Nuyts, J. et al. (2005). On deontic modality, directivity, and mood: A case study of Dutch mogen and moeten. Antwerp Papers in Linguistics, 110, 1-56.

Palmer, F. (1990). Modality and the English modals. London: Longman.

Palmer, F. (2001). Mood and modality. Cambridge: Cambridge University Press.

Perkins, M. (1983). Modal expressions in English. London: Frances Pinter.

Wided, B. (2010). Modality in English, French and Arabic biomedical discourse: A contrastive study of drug information leaflets. M.A. Dissertation, Mentouri University, Constantine.

Zayed, S.H. (1984). A pragmatic approach to modality and the modals: With application to literary Arabic. Ph.D. Thesis, University of Edinburgh, UK.

* The present research project titled Modality with Past Time Reference in English-into-Arabic Fiction Translation could not have been possible without the generous support of Kuwait University, under Project Number: AE03/14. 